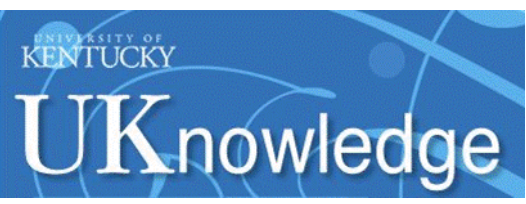

University of Kentucky

UKnowledge

$9-2015$

\title{
Manufacturing Economy vs. Service Economy: Implications for Service Leadership
}

\author{
Daniel T. L. Shek \\ University of Kentucky \\ Po P.Y. Chung \\ Hong Kong Institute of Service Leadership and Management, China \\ Hildie Leung \\ Hong Kong Polytechnic University, China
}

Follow this and additional works at: https://uknowledge.uky.edu/pediatrics_facpub

Part of the Pediatrics Commons

Right click to open a feedback form in a new tab to let us know how this document benefits you.

\section{Repository Citation}

Shek, Daniel T. L.; Chung, Po P.Y.; and Leung, Hildie, "Manufacturing Economy vs. Service Economy: Implications for Service Leadership" (2015). Pediatrics Faculty Publications. 210.

https://uknowledge.uky.edu/pediatrics_facpub/210

This Article is brought to you for free and open access by the Pediatrics at UKnowledge. It has been accepted for inclusion in Pediatrics Faculty Publications by an authorized administrator of UKnowledge. For more information, please contact UKnowledge@lsv.uky.edu. 


\section{Manufacturing Economy vs. Service Economy: Implications for Service}

Leadership

\section{Digital Object Identifier (DOI)}

https://doi.org/10.1515/ijdhd-2015-0402

\section{Notes/Citation Information}

Published in International Journal on Disability and Human Development, v. 14, no. 3, p. 205-215.

(C) 2015 Walter de Gruyter GmbH, Berlin/Boston

The copyright holders have granted the permission for posting the article here. 


\section{Daniel T.L. Shek*, Po P.Y. Chung and Hildie Leung Manufacturing economy vs. service economy: implications for service leadership}

DOI 10.1515/ijdhd-2015-0402

Received April 5, 2014; accepted June 1, 2014; previously published online August 12, 2015

\begin{abstract}
In the past few decades, there has been a shift from manufacturing to service economy in many places throughout the world. In Hong Kong, 95\% of its GDP is made up by the service industries. Conceptually, these two economies are associated with different production characteristics, organizational structures, and desired attributes of workers and leaders. The differences between these two economies in terms of the production modes are discussed in this paper. In particular, the implications of the economy on effective leadership requirements are outlined. With specific reference to the Service Leadership model proposed by the Hong Kong Institute of Service Leadership and Management, the 12 dimensions of the service-oriented personal brand and the 25 principles of service leadership are highlighted.
\end{abstract}

Keywords: industrialization; manufacturing economy; post-industrialization; service economy; service leadership; service leadership model.

\footnotetext{
*Corresponding author: Professor Daniel T.L. Shek, PhD, FHKPS, BBS, SBS, JP, Associate Vice President and Chair Professor of Applied Social Sciences, Faculty of Health and Social Sciences, Department of Applied Social Sciences, The Hong Kong Polytechnic University, Room HJ407, Core H, Hunghom, Hong Kong, P. R. China, E-mail: daniel.shek@polyu.edu.hk; Department of Applied Social Sciences, The Hong Kong Polytechnic University, Hong Kong, P. R. China; Centre for Innovative Programmes for Adolescents and Families, The Hong Kong Polytechnic University, Hong Kong, P. R. China; Department of Social Work, East China Normal University, Shanghai, P. R. China; Kiang Wu Nursing College of Macau, Macau, P. R. China; Hong Kong Institute of Service Leadership and Management, Hong Kong,

P. R. China; and Division of Adolescent Medicine, Kentucky Children's Hospital, University of Kentucky, Lexington, KY, USA Po P.Y. Chung: Hong Kong Institute of Service Leadership and Management, Hong Kong, P. R. China

Hildie Leung: Department of Applied Social Sciences, The Hong Kong Polytechnic University, Hong Kong, P. R. China
}

\section{Introduction}

The term "industrial society" was coined by sociologists to conceptualize the social characteristics and phenomenon exhibited by England and France roughly two centuries ago [1]. These characteristics included the movement of population from rural to urban areas, organized division of labor, and the systematic application of science to production, such as the invention of machines and steam engines [2]. In the industrial mode of production, workers were hired to operate machines, and they usually worked in assembly lines under instructions of line foremen. Workers were regarded as the "bottom" layer of the hierarchical decision-making process, were rarely involved in making important decisions and were distant from the final products. Hence, production under the industrial economy is mechanical and routine, where manufacturers exert heavy control over the production process and program tasks accordingly. In order to allow for more effective systemization, routinization and higher efficiency, production stages are separated and individual workers in the production line are tasked to perform specialized tasks. However, this specialization in resources has gradually been critiqued for its lack of flexibility [3].

An "economy" can be conceived as a process that transforms raw materials into something of value, which can either be tangible or non-tangible. Economies are distinguished based on its main driving force. A manufacturing economy is driven by the mass production of products [4], whereas a service economy is based on knowledgeintensive industries and services in economic production, well-educated workers in the occupational market, and innovating firms in business [5]. In the past few decades, the ongoing economic development has brought about the transition from the industrial into a post-industrial era. There has been a shift from a manufacturing economy to a service economy primarily characterized by the remarkable growth of the service industries. Service industries are made of enterprises that provide deliverables, which are intangible or immaterial [6]. The service economy is also referred to as the knowledge or information economy in the literature [7-9]. It is noteworthy that "services" in a service-oriented society are not confined to the tertiary 
sector in economy, but critical in the production of economic value in all industries $[5,10]$. Moreover, the shift of economic paradigm goes together with extensive changes in organizational and social systems, which collaboratively shape the profile of a service-driven society.

Conceptually speaking, there are different dimensions on which the emerging service economy can be differentiated from the traditional manufacturing economy (Table 1). First, concerning tangibility, the input of service economy is primarily intangible resources, such as knowledge and skills, whereas the input of manufacturing economy is tangible resources of raw materials and goods. Second, service itself as an output is also intangible, while goods produced under a manufacturing economy are tangible. Third, service production and consumption processes are inseparable (i.e. services are consumed as they are produced), and there is much interaction between clients and service providers during the service production process. In contrast, the production and consumption stages in a manufacturing economy are separated (i.e. customers purchase the goods after they are produced). This leads to the variability of services, as clients actively participate during the service production process under service economies. This is in sharp contrast to the manufacturing economy that emphasizes standardization in the production line [11-15].

The evolution of production systems toward a more customer-centered paradigm must be met with corresponding changes in structural designs of organizations and the meeting of new demands from service providers (see Table 2). The service economy calls for organization design which allows continuous organizational renewal to adapt to the changing circumstances and generate knowledge and innovations $[16,17]$. As the high level of customer contact in service production leads to increased uncertainty and diversity, organizations in the service economy must be capable of storing, sharing, and processing new information through knowledge management practices to well understand tasks and effectively provide quality services $[5,14]$. In this sense, the success of a corporation is dependent on its social assets than in physical assets. The major challenge to post-industrial organizations is to "create an environment in which knowledge accumulates and is shared at a low cost", as opposed to the endeavor of industrial firms which is to "coordinate the physical assets produced by employees" [17, p. 300]. As suggested by Collier and Esteban [16], competent organizations under the new service economy can be described as "complex adaptive systems" [18], which can serve as agencies of community by reaching beyond the boundaries of organization to multiple parties, such as customers, suppliers, local communities, consultants, academia, and others touched by the economic activities. Accordingly, an organizational structure displaying more decentralization, less formalization, and more professionalism is considered most desirable in the age of information explosion [14].

In a service-based society, people play a more crucial role than ever before [15]. Drucker [19] argued that knowledge is the only meaningful resource and knowledge worker is the single greatest asset. The mounting complex and adaptive challenges posed by the shift of economic production leads to the dependence of successful organizations on groups and coalitions of knowledgeable people sharing in the task of creating changes [20, 21]. As stated by Dentico [9], "this hyper-dynamic environment requires the full support of creative and innovative people who are searching for intrinsic satisfaction from the work they do

Table 1: Differences between manufacturing economy and service economy.

\begin{tabular}{|c|c|c|}
\hline Dimension & Manufacturing economy & Service economy \\
\hline Tangibility of & Tangible & Intangible \\
\hline production inputs & Raw materials & Knowledge and skills \\
\hline Tangibility of & Tangible & Intangible \\
\hline production outputs & Products produced can be touched & $\begin{array}{l}\text { Services have no physical presence and cannot } \\
\text { be touched }\end{array}$ \\
\hline $\begin{array}{l}\text { Variability of } \\
\text { production process }\end{array}$ & $\begin{array}{l}\text { Standardized } \\
\text { Goods produced are expected to be } \\
\text { standardized; } \\
\text { Small allowance for deviations }\end{array}$ & $\begin{array}{l}\text { Heterogeneous } \\
\text { Service involves interaction between the } \\
\text { service provider and recipient; } \\
\text { Changing situations and personalization of } \\
\text { service result in heterogeneity }\end{array}$ \\
\hline $\begin{array}{l}\text { Production and } \\
\text { consumption process }\end{array}$ & $\begin{array}{l}\text { Separable } \\
\text { Production and consumption processes are } \\
\text { separated }\end{array}$ & $\begin{array}{l}\text { Inseparable } \\
\text { Production and consumption are simultaneous }\end{array}$ \\
\hline
\end{tabular}


Table 2: Desirable organizational structures and worker attributes under the manufacturing economy and service economy.

\begin{tabular}{lll}
\hline & Manufacturing economy & Service economy \\
\hline Organizational structure & $\begin{array}{c}\text { Centralized } \\
\text { Decisions are made by authorities } \\
\text { high in organizational hierarchy }\end{array}$ & $\begin{array}{c}\text { Decentralized } \\
\text { Localized decision-making is encouraged }\end{array}$ \\
& Formalized & Less formalized \\
Organizational value & Capital assets & Human assets \\
Assumptions of workers & Machine-like & Autonomous \\
Expected roles of workers & Operators of machines & Innovators \\
Desirable attributes of & Semi-skilled & Highly-skilled and professional \\
workers & Controllable & Creative \\
& Predictable & Motivated \\
& & Possess competencies and knowledge
\end{tabular}

and are fully committed to the process of keeping abreast with and making change" (p. 176). In sharp contrast to the roles of workers in mass manufacturing economy, which are simply operators of machines, components of assembly lines or objects of management or control, the labor in service era is of very different nature. People are viewed as autonomous human beings who have competencies and knowledge, potential for construction and creation, motivational and behavioral characteristics, and power of judgment and decision $[7,16]$.

The distinction of the service economy from a manufacturing one has also been contrasted in terms of the goods-dominant (G-D) logic and the service-dominant (S-D) logic. The core belief of the S-D logic is that economic activity is a collaborative process wherein all parties, including customers, partners and employees, co-create value through reciprocal service provision [22]. In the G-D logic, goods (i.e. tangible output embedded with value) are the primary focus of economic exchange, and services are just regarded as either a restricted type of intangible goods or an add-on that enhances the value of goods. In contrast, the S-D logic points to the primary role of services in economic exchange, considering service in its own right without reference to goods [12]. In particular, the G-D logic views value as something produced and sold, customers as isolated entities and targets of exchange, resources as operands (i.e. tangible, static resources that require some action to make them valuable), and efficiency as the key principle. In contrast, the S-D logic regards value as something co-created with the customer and other valuecreation partners; it also views customers as supportive resources with their own networks, resources as operands (i.e. intangible, dynamic resources that are capable of creating value), and efficiency as a goal to be achieved through effectiveness [12, 23].

In short, the term "service economy" stands for an emerging economic structure, which is characterized by the great growth of services in the production of value or wealth and the decisive role of intangible assets such as knowledge, skills, and innovation in economic success, as opposed to the industrial economy wherein production mainly takes the form of manufacturing $[5,7,24]$. Moreover, service economy also implies a state of society, in which individuals, organizations and social systems operate in a way that is determined by the service-oriented economic activities. Of course, when the terms "manufacturing economy" and "service economy" are used, it should be noted that they are regarded as ideal types in this paper. In reality, manufacturing and service industries exist in many places, although their relative weights are different.

\section{Desirable leadership characteristics in the manufacturing and service economies}

With the transition of economic production from a manufacturing mode to a service mode, the incongruence between the traditional style of leadership and the needs of the new economy is becoming more evident. Given the rapid change, turbulence, diversity and ambiguity in the environment, leadership that can develop the capacity of organizations and people to respond to the complex adaptive challenges as well as produce knowledge and innovations is expected to replace the traditional paradigm of leadership that is based on machine-like assumptions $[9,25,26]$.

Several dimensions can be used to contrast the leadership qualities desired in these two economies (Table 3). First, instead of individual leaders as the primary actors of leadership in the manufacturing age, the emphasis of new leadership paradigm is placed on relationship wherein 
Table 3: Desired leadership attributes under the manufacturing economy and service economy.

\begin{tabular}{|c|c|c|}
\hline & Manufacturing economy & Service economy \\
\hline \multirow[t]{2}{*}{ Leadership style } & $\begin{array}{l}\text { Highly autocratic } \\
\text { Minimal input from followers } \\
\text { in decision-making processes }\end{array}$ & $\begin{array}{l}\text { Distributed } \\
\text { Shared decision-making } \\
\text { between leaders and followers } \\
\text { Communication encouraged }\end{array}$ \\
\hline & $\begin{array}{l}\text { Transactional } \\
\text { Delegation of tasks from } \\
\text { leaders to followers } \\
\text { Minimal empowerment and } \\
\text { communication between } \\
\text { leaders and followers }\end{array}$ & $\begin{array}{l}\text { Transformational } \\
\text { Empowerment of followers is } \\
\text { encouraged }\end{array}$ \\
\hline Leadership attributes & Directive & $\begin{array}{l}\text { Flexible } \\
\text { High in openness } \\
\text { Collaborative } \\
\text { Motivated }\end{array}$ \\
\hline Leadership goals & $\begin{array}{l}\text { To satisfy the needs of } \\
\text { manufacturers }\end{array}$ & $\begin{array}{l}\text { To satisfy the needs of those } \\
\text { being served and society }\end{array}$ \\
\hline
\end{tabular}

"leaders and collaborators influence one another about real changes that reflect their mutual purposes" [21, p. 11]. Due to the growing complexity of tasks in the service economy, decision-making has increasingly become a multidisciplinary process that requires association, interaction, and collaboration among leaders, followers, and other involved agencies possessing different resources $[9,25]$. The goals defined by the whole group or organization direct leadership in the post-industrial context, rather than the wishes of leaders only, as practiced in the traditional model of leadership [20, 21]. As suggested by UhlBien et al. [17], "leadership is not merely the influential act of an individual or individuals but rather is embedded in a complex interplay of numerous interacting forces" (p. 302).

Second, consistent with the nature of post-industrial leadership, which is more about relationship building based on mutually agreed purposes, the leadership structure is characterized by flexibility, openness and autonomy, in contrast to the industrial model that adopts a top-down, hierarchical, and autocratic approach [16, 27]. Only organizations with managerial autonomy, crossboundary collaboration, and freedom of taking risks and accountability can develop effective responsiveness to the changing environmental and technological conditions [16]. Each member of an organization is regarded as a valuable asset with an important role in the decisionmaking and the knowledge creation. "Conversation" therefore becomes the key channel in which leaders and knowledge workers share useful information and identify the collective objectives, and create an environment that facilitates productive communication within and outside organizations, which in turn, becomes vital to effective leadership in the knowledge age [28].

Third, different from industrial leadership, which is usually task-focused and coercion-based, leadership in the service economy emphasizes the empowerment of individuals and groups and regards such empowerment as the strongest impetus of sustainable achievement of organizations [29]. Rost [21] remarked that the 20th century school of leadership is simply "good management”, which is far from meeting the requirements proposed by the new economy. In an environment with ever-changing adaptive challenges, the ability to learn and evolve is crucial to the successful survival of any individual or organization. Hence, an important topic faced by contemporary leaders is how to develop human capacity to the largest extent [20]. It is commonly suggested that intelligent leaders must be able to create conditions under which staff members' needs are satisfied, personal development is nurtured, and individuals' characteristics are aligned with organizational achievement [30, 31]. Similar arguments are held by advocates of transformational leadership model who thought that leaders should inspire and motivate people to achieve beyond their capability through positive influences [32]. More specific advice is given by Webber [33] that leaders have to "attract and motivate the best people; reward, recognize, and retain them; train, educate, and improve them - and, in the most remarkable reversal of all, serve and satisfy them" (p. 27). On an even broader level, Rost and Barker [27] contended that in the postindustrial world, leadership must serve the general needs of society rather than the exclusive needs of corporations or corporate executives. 


\section{The service leadership and management model (SLAM)}

Most advanced industrialized economies are now dominated by service employment, as evidenced by a large service sector share of the Gross Domestic Product (GDP). In 2012, the service industry contributed $79 \%$ of the nation's GDP in the US, 78\% in the UK, 71\% in Germany, $73 \%$ in Japan, and 93\% in Hong Kong [34]. The expansion of service employment calls for the development of a leadership model to meet the needs of the service-oriented societies. As such, the Service Leadership and Management Model (SLAM) was developed [35], where service leadership "...is about satisfying needs by consistently providing quality personal service to everyone one comes into contact with, including one's self, others, groups, communities, systems, and environments. A service leader is a ready, willing and able, on-the-spot entrepreneur who possesses relevant task competencies and is judged by superiors, peers, subordinates, and followers to exhibit appropriate character strengths and a caring social disposition". Chung argued that, effective service leadership is a function of moral character, leadership competencies, and a caring disposition. The SLAM provides a framework to answer the "Who, What, and How" questions pertaining to service provision in today's society.

"Who are the service leaders and service recipients?"

The respective organizational structures delineating leadership roles are different between the two economies. In manufacturing economies, organizational forms are known as machine bureaucracy. Organizations are arranged mechanistically, with high vertical and horizontal task differentiation, low integration across functions and limited tolerance for deviations in production. Power and control are based on one's position in the bureaucratic hierarchy, and leaders are usually authoritarian [36]. On the contrary, in service economies, horizontal and vertical conversations, collaboration, and flexibility are valued in organizations [28]. Townsend and Gebhardt [37] made an interesting distinction between "capital-L" leadership and "small-l" leadership. "Capital-L" leadership is the classic form of leadership conceptualized in a heroic sense, where leadership positions are held by individuals who are high in the hierarchy, and those who make bold decisions are able to inspire all and impact many lives. Basically, they are those who are at the top of the corporate pyramid, "everyone else in the organization becomes a leadership-wanna be". In comparison, "small-l" leadership "occurs when individuals interact in day-to-day operations throughout an organization... [it] is exemplary followership with superior skills" (p. 139). The vigilant organization of manufacturing operations makes it easier for managers to observe the individual performance of each worker along the production line, and leadership can remain at the top-level of the hierarchy. However, in service economy, it is impossible for management to monitor every employee's interaction with each customer. As such, organizations in today's economy aim at developing "small-1" leadership among employees, where leadership at every level becomes equally important [37].

The notion of "small-l" leadership is in line with the SLAM, which suggests that "every day, every human occupies a position of leadership and possesses the potential to improve her leadership quality and effectiveness" [35]. The role of service leader is not confined to certain individuals who possess particular leadership competencies or those who are in authority positions, rather, all individuals have the opportunity to provide service to those with whom one comes into contact with during all daily interactions, both personally or professionally. Furthermore, service leadership "is about creating new personal service propositions and consistently providing high quality caring service to everyone one comes into contact with, including one's self" [35]. This echoes the idea of Rost and Barker [27], who argued for the need of postindustrial leaders to consider not only self-interests, or needs of one's organization, but also the needs of society. To answer the "Who" question, based on the SLAM, individuals who are not considered as "leader-wanna be"s are stigmatized under traditional "capital-L" leadership models, since in essence, we are all service leaders who aim to provide quality service to everyone we interact with.

“What kind of service should be provided by a service leader?”

Service leadership is concerned with the provision of high quality personal service. "Personal" is the key in high quality service provided in today's economy, as starkly contrasted with "standardized" outputs produced in a manufacturing economy. While an industrial society is dominated by the man-machine relationship, a man-man relationship is emphasized under a post-industrial society [38]. In a post-industrial economy, "the basic experience of each person's life is his relationship between himself and others" [38, p. 47]. In the service leadership model, it is concerned about the "Service Leader-Service" relationship focusing on the bi-directional interplay between one's identity and service provided to others. Service leaders' identities are defined by the service he/she provides to those whom he/she comes into contact with. As 
described by Chung [39], "The server is the service. The personal character, skills, and caring of the human being providing the service determines how successful that service will be and what opportunities will grow from it. Enhancing service means nothing less than nurturing, encouraging, and developing the individual who serves. I consider these qualities, traits, and abilities to be the core 'content' of service” (p. 2).

Studies have demonstrated the importance of morality and ethical reasoning for service providers in service contexts, such as healthcare or education [40, 41]. The crux of the human service organization is that its work on people must be guided by moral and ethical values. In addition, "to the recipients of human services, human service organizations are expected to embody the values of caring, commitment, trust, and responsiveness to human needs" [42, p. 10]. Service providers are not only expected to perform professionally, but also to serve ethically and empathically. Organizational efficiency and leadership demands in today's service economy place great value on personal qualities rather than merely academic abilities, as pointed out by an employer, "academic qualifications are the first tick in the box and then we move on" [43, p. 31]. By the same token, leadership competencies alone are insufficient for effective service leadership. The service leader's moral character and caring disposition are of equal importance in the provision of high quality service.

"How can a service leader ensure the provision of high-quality service?”

According to Chung [39], service leaders are conceived as personal organizations, which he refers to as, "Me, incorporated". Based on his contention, individuals are all managers of "Me, incorporated" (i.e. our own life) and possess the free will to make choices accordingly. In order for our organization to succeed in providing high quality service to others, we must first be able to manage ourselves with self-discipline, and to allow time for personal reflection, conversation and consultation. Specifically, the SLAM suggests that "service includes self-serving efforts aimed at ethically improving one's competencies, abilities, and willingness to help satisfy the needs of others". Service leaders must be intrinsically motivated to lead oneself toward continuous self-improvement. Moreover, one cannot lead an organization before leading oneself.

The advancement toward a knowledge economy calls for problem-solving, communication, teamwork, and self-management skills among employees [44]. Selfmanagement is concerned with the application of strategies designed to enhance employee behaviors to meet organizational needs, particularly for tasks that are not intrinsically motivating. Individuals apply self-management strategies mainly to gain extrinsic rewards (e.g. salary, praise, external recognition). As such, the theory has been critiqued for overlooking the influence of intrinsic motivation in performance. Thus, Manz [45] proposed the notion of self-leadership which incorporates the role of intrinsic motivation in changing behaviors, and developed a set of behavioral and cognitive self-leadership strategies that enable individuals to manage, influence, and lead oneself to establish self-direction and motivation to reach goals and perform effectively. In this sense, service leadership transcends self-management, and is driven by self-leadership.

On the one hand, performance in manufacturing economy is often assessed in quantities (e.g. amount of products made on an hourly basis), creating a work environment that is output-oriented. Reward systems are devised in accordance to quantities of output. On the other hand, service economy is highly concerned about the quality of interaction between service providers and their recipients. It is likely that workers in manufacturing economy are more motivated by extrinsic rewards, whereas employees in service economy are more driven by intrinsic reinforcements. Research has shown that intrinsic rewards have a greater impact on customer-oriented behaviors and customer service quality than extrinsic rewards [46]. These findings support the importance of self-leadership, which is concerned with the notion of intrinsic motivation for service leaders. Chung [39] further applies Maslow's hierarchy of needs to illustrate that workers in the service industry are motivated by needs beyond the physiological levels, and aim to satisfy higherorder needs through their service provision. In response to the question of "how service leaders can ensure the provision of high-quality service", service leaders are expected to take on a self-leadership role to intrinsically motivate oneself to strive for continuous improvement and nurturance of one's leadership, moral, and interpersonal competencies.

\section{The 25 principles of service leadership}

The skill base of a manufacturing economy consists of engineering and semi-skilled workers. The skills that are required of these workers are far narrower than those of an employee today. The skill base of a service economy constitutes scientist, technical, and professional occupations 
[38]. Professionals are all service providers, "The physician provides service by healing sick people; the teacher is a servant of knowledge; the architect creates aesthetic structures for people's enjoyment while ensuring their safety..." [47, p. 7]. Against this background, Chung [48] proposed 25 principles of service leadership as shown in Table 4. The principles serve as a "curriculum" targeted at individuals who are interested in understanding service, providing high quality service or effectively managing service, which apparently, includes everyone.

The shift from a goods-centered to customer-centered mode of production requires an organizational culture that allows flexibility, continuous growth, management of knowledge, and the generation of innovation [17]. This is in line with Chung's [48] Principle of Habitat Management, highlighting the importance of maintaining a healthy habitat. In fact, principles under the category of Service Situations outline organizational culture characteristics that should be adopted by service organizations to meet the aforementioned goals. In addition, service economy concerns man-man relationships, as opposed to the man-machine relationship of the industrial era [38]. The quality of service provider-recipient and leader-follower relationships is highly valued, as reflected in The Principles of Relationship, Mentor-follower, and People leadership.

As opposed to the tangible nature of products from factories, the intangible nature of service implicates the requirements of service leaders [49]. First, as customers are unable to "touch or feel" services before they actually purchase it, it is difficult for them to determine or predict its value. Thus, the word of mouth from previous customers becomes critical, as advocated by The Principle of Global Extension of Relationships. Second, it is often impossible to patent intangible services, and this situation creates fierce market competition. Successful service enterprises are those that create powerful brands [49], those that competitors find difficult to copy and customers find hard to replace. In order to do so, service leaders must create a personal brand (The Principle of the Personal Brand), which provides exceptional high quality services (e.g. The Principle of the 3C's; Trust, Fairness, Respect, and Care; Service Mindset). Furthermore, the service economy capitalizes on human resources and knowledge, as opposed to merely capital assets in the manufacturing economy. Successful service organizations must value and motivate their employees (The Principle of Mentor-Follower; Authoritarian Leadership and Distributed Leadership; Transformation and Inspiration). However, the responsibility of developing human capital should not be weighed solely on organizations, a personal pursuit of continuous improvement and proactive efforts are also crucial to establishing reliable services [50]. Thus, service leaders should constantly engage in self-reflection (The Principle of Who You Are) and manage oneself accordingly (The Principle of Self-Leadership).

\section{The 12 dimensions of service leadership}

In order to provide high quality service, self-reflection on one's service experiences (both in providing and receiving service), and an honest evaluation of one's strengths and weaknesses as service leaders are crucial for continuous development. Chung [51] identified 12 dimensions in relation to our personal brand which serves as a framework highlighting the desirable qualities of leadership under the service economy (see Figure 1). The 12 dimensions are categorized into four domains, including doing, thinking, being, and growing. Manufacturing economy relies on employees' functional expertise, specifically, skills on engineering and knowledge in machine technology. In contrast, while functional expertise is also emphasized under the service economy, it is not sufficient for success. Service leaders are required to possess a wide range of skills in addition to their task and leadership competencies (as categorized under the act of "doing" of the 12 dimensions) on an interpersonal and intrapersonal level.

For instance, regarding the second category of "thinking”, studies have shown the linkage between emotional intelligence of service providers and customer satisfaction [52]. Furthermore, while manufacturing enterprises desire uniformity and the production of consistent outputs, service requires personalization with adaptability and flexibility becoming the critical attributes. Take the example of a customer service representative, customer requests are surely not routine; thus, responses from service providers cannot be uniform [53]. Service leaders are required to be "on one's feet" at all times to skillfully handle diversified demands from service recipients. In addition, knowledge functions as a strategic resource in a post-industrial society, and knowledge management is the axial principle guiding its development. As such, the mental attributes (intellectual dimension) encompassing logical and critical thinking, effective information gathering, and decision-making enables service providers to better adapt under service economy's unpredictability and in managing knowledge.

The third category is the attribute of "being". The Spiritual-Habitat dimension pertains to an individual's 
Table 4: The 25 service leadership principles (adapted from Chung [48]).

Service leadership principle Summary of principle

1. The principle of $15 \mathrm{~min}$ of leadership

2. The principle of self-leadership

3. The principle of people leadership

4. The principle of the server

5. The principle of competence, character, and care (the three C's)

6. The principle of co-created service leadership

7. The principle of who you are

8. The principle of personal ethics

9. The principle of who you hire

10. The principle of authoritarian leadership and distributed leadership

11. The principle of trust, fairness, respect and care

12. The principle of POS (Personal Operating System)

13. The principle of personal brand

\section{The heart of service}

14. The principle of relationship

15. The principle of service

16. The principle of mentor-follower

17. The principle of historical service development

18. The principle of non-tradable service 19. The principle of service mindset

\section{Service situations}

20. The principle of transformation and inspiration

21. The principle of global extension of relationships

22. The principle of habitat management

23. The principle of maritime mindset

24. The principle of Anna Karenina

25. The principle of wrapped service (i.e. The Hamburger Principle)
Everyone will have the opportunity to be a service leader. How one makes wise use of his/ her time as a service leader is critical.

If one can lead him/herself in positive, productive, and healthful ways, it is the best indication that he/she can also lead others.

Service leaders' work is tied inextricably to the needs and responses of actual people. Service is a higher level, significantly evolved human activity that deserves admiration from others, self-respect, and the satisfaction of social contribution within the server. Excellent service is characterized by a service leader's competencies (i.e. one's ability to apply knowledge and skills in productive and meaningful ways), character (i.e. positive traits such as honesty, reliable, integrity, willingness to work with others, etc.), and care (i.e. sincerity, empathy to those one serves).

Service is co-created; both the server and the person served play active roles in the relationship.

Self-awareness enables service leaders to be open and receptive to the service relationship.

Service leaders must serve by knowing what is right, and acting in moral ways at all times. In hiring employees, sound character surpasses the importance of technical skills. There are advantages and disadvantages of authoritarian and distributed leadership. Effective leadership depends on the appropriate exercise of leadership styles in line with the team/organization's goals.

Trust, fairness, respect, and care are the "secret ingredients" that distinguish successful service experiences from unsuccessful ones.

The Personal Operating System of service leaders defines "who they are". It is thus important for one to safeguard their POS against moral 'attackers', and to maintain noble motives, care, and sincerity in service.

Each service leader represents a personal corporation ("Me Inc."). It is the mission of each "Me Inc." to embody and serve with character traits, skills, and initiative that will positively impact those whom they come into contact with.

The crux of excellent service is a healthy, mutually sustained relationship between the serve and the person being served.

To meet the demands of today's service economy, it is important to locate core principles that educators and company trainers can use to develop curricular and on-the-job training programs to improve service at all levels.

Mentor-apprentice models are beneficial to companies. These professional relationships enable learning and sharing of experiences.

Service is the core of humanity. The pleasures one experiences in serving others and being served are innate, universal, and historically rooted.

Service, although non-tradable, has real value.

Service leaders must adopt a "service mindset" characterized by an automatic and genuine demonstration of care for others' needs.

True service leadership is to provide transformative solutions to problems and inspire those served to be agents of transformations.

Service leaders should provide service that will enable the establishment of credible global reputation and relationships; quality service that exceeds expectations of those being served.

Service leaders are responsible for the immediate habitat (i.e. environment/culture) of the service organization. They must closely monitor and maintain the health of the service habitat.

Service organizations should aim to provide high quality service at all times and strive to build strong bonds of integrity with their customers.

No quantity of good deeds can make up for the consequences of a single error. Service leaders must predict and avoid errors that are costly to one's service reputation. No products exist by itself. They are in fact, "wrapped" in service. Services are a major way of differentiating between one product and another. 


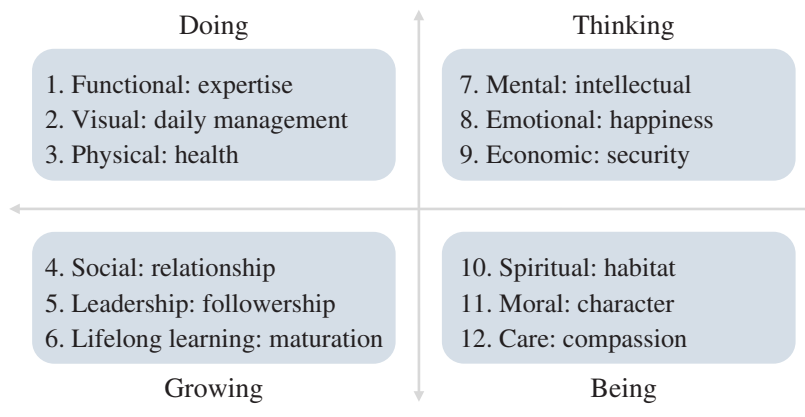

Figure 1: The 12 Dimensions of the service-oriented personal brand (Chung, [51]).

connection to things that transcend individual selfinterests and materialistic possessions. It is about one's meaning in life and how one can contribute to something beyond what is immediate. Spirituality is inherent to service, and as claimed by Deikman [54], "service is a way of knowing, a way of making deeper contact with the interconnectedness of reality we call 'spiritual'” (p. 30). Similarly, Tesone [47] stated that "a path of service is a choice we make, while one of servitude is forced upon us" (p. 7). Employers in the service economy are inclined to hire candidates who are motivated to provide customers with personalized service for long periods of time, and this can only be achieved by those who have a genuine attitude to serve [47]. One's calling becomes an important catalyst for genuineness in service.

An additional distinction between manufactured products and service delivered is its ownership. Products are purchased by customers who subsequently own what they have paid for; hence, it is a one-off transaction. In services, however, clients pay for the use of the services (e.g. patrons do not own restaurants, taxis, or flights) but not its ownership. This implies that service providers must find ways to emphasize the value of service during the moment of exchange between the service provider and recipient so that the relationship can last. Therefore, branding becomes imperative in a service economy as it enhances the prolonged perceptions of utility to secure future demands for the service [49]. One can do so through the provision of high quality service. If customers are confident that the services they receive from the service leaders are reflective of the leaders' values and dispositions (which presumably are consistent), customers can expect reliability in the quality of service over time. In fact, studies showed that in customers' mind, they find it difficult to differentiate between services from the people who provide the service [55]. This underscores the importance of both the character attribute under the moral domain and the compassion attribute under the care domain.
The fourth category is the act of "growing". The SocialRelationship dimension is concerned about the characteristics that service providers possess, which either attract or repel service recipients. Individuals who are highly competent in this dimension are often humorous, compassionate, and able to contribute to a group's happiness. Products are produced, while services are "performed". The service recipient, as an audience, is attentive and sensitive to the service they receive. The style of the performance and whether it is appealing directly affects customer satisfaction and the price one can charge for the service. As such, every service encounter between the performer and his/ her audience is critical as it poses a chance to "make it or break it"; determining whether the service providercustomer relationship will deepen and endure [49]. The Leader-Followership dimension is particularly important in a service economy. Leadership roles in a manufacturing economy are taken by those at the top of the organization hierarchy, and decisions are made by these powerful authorities. However, in service economy, leadership is concerned with empowering staff at all levels in order to ensure sustainable achievement of organizations; in such a case, localized decision-making is encouraged [29]. The above are examples of how various dimensions are related to the requirements of today's service economy, Chung [51] provides a more detailed account of how each dimension is associated with the demands of the service age.

There have been significant changes since the industrial era; specifically, the economies of developed nations are increasingly dominated by the service sector. The shift from manufacturing to service economy demands a wider skill set from the working population. Technical skills have become merely a prerequisite for entrance into the job market; to succeed in the service economy, one must also possess interpersonal and intrapersonal competencies, such as moral character and caring dispositions. To conclude, Chung [35] shrewdly puts it, "employees (service leaders, in our case) at their best perform more like orchestral conductors than as cogs in a machine. They are sensitive to their business environment, adaptive to their audience, and committed to making harmony, not noise, in their business lives" (p. 149). With reference to these changing conceptions, the next question is how we can nurture service leaders who can thrive under the service economy. To promote the development of service leadership curriculum in the higher education sector in Hong Kong, the Victor and William Fung Foundation initiated and fund the Service Leadership Initiative [56]. It is expected that this new initiative will help to nurture the service leadership qualities in the future generations of university students in Hong Kong. 
Acknowledgments: The Service Leadership research project at The Hong Kong Polytechnic University is financially supported by the Victor and William Fung Foundation.

\section{References}

1. Kennedy D. Industrial society: requiem for a concept. Am Sociol 2011;42:368-83.

2. Aron R. Eighteen lectures on industrial society. London:Weidenfeld Nicolson, 1961.

3. Boehlje M. Industrialization of agriculture: what is it? what does it mean? Feedstuffs 1996;68:14-7.

4. McDowell L. Working bodies: interactive service employment and workplace identities. West Sussex, UK: Wiley-Blackwell, 2009.

5. Brinkley I. Defining the knowledge economy: knowledge economy programme report. London: The Work Foundation, 2006.

6. Bryson JR, Daniels PW, Warf B. Service worlds: people, organisations, technologies. London: Routledge, 2004.

7. Bandt JD. The concept of labour and competence requirements in a service economy. Ser Ind J 1999;19:1-17.

8. Buera FJ, Kaboski JP. The rise of the service economy. NBER Working Paper No. 14822 2009. Available at: http://www.nber. org/papers/w14822. Accessed on November 8, 2013.

9. Dentico JP. Games leaders play: using process simulations to develop collaborative leadership practices for a knowledgebased society. Career Dev Int 1999;4:175-82.

10. Giarini $\mathrm{O}$. Basic features of services and some fundamentals of the (new) service economy. Progress 2001;33:20-8.

11. Kotler P, Armstrong G. Principles of marketing. Upper Saddle River, NJ: Pearson Education, 2006.

12. Vargo SL, Lusch RF. From goods to service(s): divergences and convergences of logics. Ind Market Manag 2008;37:254-9.

13. Vargo SL, Lusch RF. Why "service"? J Acad Mark Sci 2008;36:25-38.

14. Chowdhury S, Miles G. Customer-induced uncertainty in predicting organizational design: empirical evidence challenging the service versus manufacturing dichotomy. J Bus Res 2006;59:121-9.

15. Wilderom CP. Service management/leadership: different from management/leadership in industrial organisations? Int J Ser Ind Manag 1991;2:6-14.

16. Collier J, Esteban R. Systemic leadership: ethical and effective. Leadership Organ Dev J 2000;21:207-15.

17. Uhl-Bien M, Marion R, McKelvey B. Complexity leadership theory: shifting leadership from the industrial age to the knowledge era. Leadership Quart 2007;18:298-318.

18. Anderson P. Perspective: complexity theory and organization science. Organ Sci 1999;10:216-32.

19. Drucker PF. Post-capitalist society. New York, NY: Harper Business, 1993.

20. Allen KE, Stelzner SP, Wielkiewicz RM. The ecology of leadership: adapting to the challenges of a changing world. J Leadership Organ Stud 1999;5:62-82.

21. Rost JC. Moving from individual to relationship: a postindustrial paradigm of leadership. J Leadership Organ Stud 1997;4:3-16.

22. Lusch RF, Vargo SL, O'Brien M. Competing through service: insights from service-dominant logic. J Retailing 2007;83:5-18.
23. Lusch RF, Vargo SL, Wessels G. Toward a conceptual foundation for service science: contributions from service-dominant logic. IBM Syst J 2008;47:5-14.

24. Stahel W. The utilization-focused service economy: Resource efficiency and product-life extension. In: Allenby BR, Richards DJ, editors. The Greening of industrial ecosystems. Washington, DC: National Academy Press, 1994:178-90.

25. Gibney J, Copeland S, Murie A. Toward a 'new' strategic leadership of place for the knowledge-based economy. Leadership 2009;5:5-23.

26. Heifetz RA. Leadership without easy answers. Cambridge, MA: Belknap Press/Harvard University Press, 1994.

27. Rost JC, Barker RA. Leadership education in colleges: toward a 21st century paradigm. J Leadership Stud 2000;7:3-12.

28. Barlow DH. What's new about evidence-based assessment? Psychol Assess 2005;17:308-11.

29. Brungardt CL. The new face of leadership: implications for higher education. 1998. Available at: http://www.nwlink.com/ donclark/ leader/lead_edu.html. Accessed on November 8, 2013.

30. Rausch E. More effective leadership can bring higher service quality. Manag Serv Qual 1999;9:154-7.

31. Rausch E, Halfhill SM, Sherman H, Washbush JB. Practical leadership-in-management education for effective strategies in a rapidly changing world. J Manag Dev 2001;20:245-57.

32. Bass BM. Transformational leadership: Industrial, military, and educational impact. Mahwah, NJ: Lawrence Erlbaum Associates, 1998.

33. Webber AM. What's so new about the new economy? Harvard Bus Rev 1993;71:24-42.

34. The World Bank. World development indicators: by structure. The World Bank; 2013. Available at: http://data.worldbank.org/ indicator/NV.SRV.TETC.ZS/. Accessed on November 8, 2013.

35. Chung PP. Transformative paradigm shifts. Hong Kong Institute of Service Leadership and Management Limited, 2010. Available at: http://hki-slam.org/index.php? $r=$ article \& catid=3\&aid=34. Accessed on November 8, 2013.

36. Nemetz PL, Fry LW. Flexible manufacturing organizations: implications for strategy formulation and organization design. Acad Manag Rev 1988;13:627-38.

37. Townsend P, Gebhardt JE. For service to work right, skilled leaders need skills in "followership”. Manag Serv Qual 1997;7:136-40.

38. Bell D. Welcome to the post-industrial society. Phys Today 1976;29:46-9.

39. Chung PP. Service reborn: the knowledge, skills, and attitudes of service companies. Hong Kong: Lexingford Publishing, 2012.

40. McCormick J, Rodney P, Varcoe C. Reinterpretations across studies: an approach to meta-analysis. Qual Health Res 2003;13:933-44.

41. Bullough Jr RV. Ethical and moral matters in teaching and teacher education. Teach Teach Edu 2011;27:21-8.

42. Hasenfeld Y. Human services as complex organizations. London: Sage, 2010.

43. Brown P, Hesketh A. The mismanagement of talent: employability and jobs in the knowledge economy. Oxford: Oxford University Press, 2004.

44. Ashton D, Felstead A, Green F. Skills in the British workplace. In: Coffield F, editor. Differing visions of a learning society: research findings, Volume 2. Bristol: Policy Press, 2000:193-228. 
45. Manz CC. Self-leadership: toward an expanded theory of self-influence processes in organizations. Acad Manag Rev 1986;11:585-600.

46. Hoffman KD, Ingram TN. Service provider job satisfaction and customer-oriented performance. J Serv Market 1992;6:68-78.

47. Tesone DV. Supervision Skills for the Service Industry: how to do it. Upper Saddle River, NJ: Pearson Prentice Hall, 2005.

48. Chung PP. The 25 Principles of Service Leadership. In press.

49. Young L. From products to services: insights and experience from companies which have embraced the service economy. West Sussex, UK: John-Wiley, 2008.

50. Malhotra NK, Ulgado FM, Agarwal J, Shainesh G, Wu L. Dimensions of service quality in developed and developing economies: multi-country cross-cultural comparisons. Int Market Rev 2005;22:256-78.
51. Chung PP. Your second skin. Managing the 12 dimensions of your personal brand for the service age. In press.

52. Othman AK, Abdullah HS, Ahmad J. Emotional intelligence, emotional labour and work effectiveness in service organisations: a proposed model. J Bus Perspec 2008;12:31-42.

53. Varca PE. Service skills for service workers: emotional intelligence and beyond. Manag Serv Qual 2004;14:457-67.

54. Deikman AJ. The spiritual heart of service. Noetic Sci Rev 1997; Winter:30-5.

55. Zeithaml VA, Bitner MJ. Services marketing: integrating customer focus across the firm, 3rd editon. Boston, MA: McGrawHill Irwin, 2003.

56. Shek DT, Yu L, Ma CM, Sun RC, Liu TT. Development of a creditbearing service leadership subject for university students in Hong Kong. Int J Adoles Med Health 2013;25:353-61. 